\title{
Assessment of Land use and Land Cover Changes in Savar Upazila under Dhaka District in Bangladesh: A Remote Sensing (RS) - Geographic Information System (GIS) Approach
}

\author{
Md. Shahjahan Ali* and Md. Abdus Salam**1 \\ * Principal Scientific Officer, Bangladesh Space Research and Remote Sensing Organization (SPARRSO) \\ Agargaon, Sher-e-Bangla Nagar, Dhaka-1207, Bangladesh \\ **11 Chief Scientific Officer, Bangladesh Space Research and Remote Sensing Organization (SPARRSO) \\ Agargaon, Sher-e-Bangla Nagar, Dhaka-1207, Bangladesh \\ ${ }^{\mathbf{1} C o r r e s p o n d i n g ~ a u t h o r ' s ~ e m a i l ~ a d d r e s s: ~ s a l a m 2 b d @ g m a i l . c o m ~}$ \\ DOI: 10.29322/IJSRP.11.12.2021.p12057 \\ http://dx.doi.org/10.29322/IJSRP.11.12.2021.p12057
}

\begin{abstract}
Land use and land cover changes is a dynamic phenomenon both in rural and urban areas of Bangladesh as the population growth is in positive trend. The changes are comparatively higher or faster in the periphery of urban area compare to rural area as the population pressure is higher in urban area than rural area. The urbanization has been occurred for settlement and for micro or macro level industrialization also. Having the unique capability of remote sensing for synoptic viewing, real time and repetitive coverage offers a potential tool for monitoring the earth surfaces. In the present research a study has been undertaken to assess the land use and land cover changes by using the high resolution aerial photographs and freely available moderate resolution satellite remote sensing data in Savar Upazila under Dhaka District in Bangladesh. High resolution aerial photographs of 1983 and moderate resolution Sentinel 2 data for the year 2020 have been used for this purpose. A comparison of different land use and land cover classes has been done between the year 1983 and 2020. Driving forces behind the changes of land use and land cover has also been investigated through GPS (Global Positioning System) based ground verification and interview with the people.
\end{abstract}

Index Terms- Areial Photograph, Sentinel 2, Remote Sensing, Spectral properties, GIS.

\section{INTRODUCTION}

Environmental degradation is usually demonstrated through various indicators of environmental parameters. i.e. loss of vegetation cover, increasing salinity covered bed of land, decreasing the agricultural land etc., which may impact local and regional environment. (Gain, 1998). The potential utility of remote sensing data has been well recognized in mapping and assessing land attributes such as physiography, soils, land use/land cover, etc. (Solanke Preeti et al. 2005). The Increase of vegetation cover and changes in land use pattern has been investigated using remote sensing satellite data. Digital analysis found the significant changes. Particularly on the burned land that has been transformed mostly into vegetation (Rahman et al. 2007). Control of resources, proper plan, and management of human activities (unplanned settlement, land use, deforestation and underground water use) can enhance the way to execute sustainable development and management (Riches, 2008). Remote sensing is useful tool for mapping the surface cover types such as land, water and vegetation. (Haque et al. 2012). A study conducted using remote sensing data to investigate the changes in land-use and land cover of St. Martin Island. Satellite images were analyzed to detect changes in land use and land-cover in the last 
40 years and it has been found that the causes of land use and land cover changes were the human pressure in the island (Ali et al. 2017). Remote Sensing and GIS techniques for identification and evaluation of land use pattern in Nachole Upazila of Bangladesh reveals that the improper and irrational uses of land hindered the sustainable development and management of natural resources (Ali et al. 2018). At the present time, Environment is a big issue in both national and international context. Due to our inconsiderable activities toward environment, many natural resources are already extinct and many of others are in danger for extinction. Monitoring of the land use and land cover change is very important for sustainable use and development of natural resources. Finding land use and land cover changes by use remote sensing is the better way than any other conventional method.

Therefore the present study has been undertaken with the aim of developing a method for land use and land cover assessment by using the remote sensing data. The following objectives would be taken into consideration:

- $\quad$ Preparation of land use and land cover map;

- Identification and understanding the underlying causes of land use and land cover changes;

- Generation of data set and statistics;

\section{Study area}

\section{MATERIAL AND METHOD}

Q tudy area has been undertaken in Savar Upazila of Dhaka District in Bangladesh (Figure 1). It is about 25 kilometers away towards the northwest of Dhaka city center. The study area is situated within $23^{\circ} 44^{\prime} 22.18^{\prime \prime}$ and $24^{\circ} 03^{\prime} 18.03^{\prime \prime} \mathrm{N}$ latitude and $90^{\circ}$ $10^{\prime} 28.66^{\prime \prime}$ and $90^{\circ} 10^{\prime} 43.50^{\prime \prime}$ E longitude. It is surrounded by bounded by Kaliakair and Gazipur Sadar upazilas on the North, Keraniganj upazila on the south, Mirpur, Mohammadpur, Pallabi and Uttara thanas of Dhaka City on the east, and Dhamrai and Singair upazilas on the west. Main rivers are Bangshi, Turag, Buriganga and Karnatali. The Bangshi River has become polluted due to industrial waste. Mixture of relatively low and moderately high land characterizes landscape of the area. The area is fragmented into small patches and intermingled with the neighboring settlements. The climate of this area is tropical.

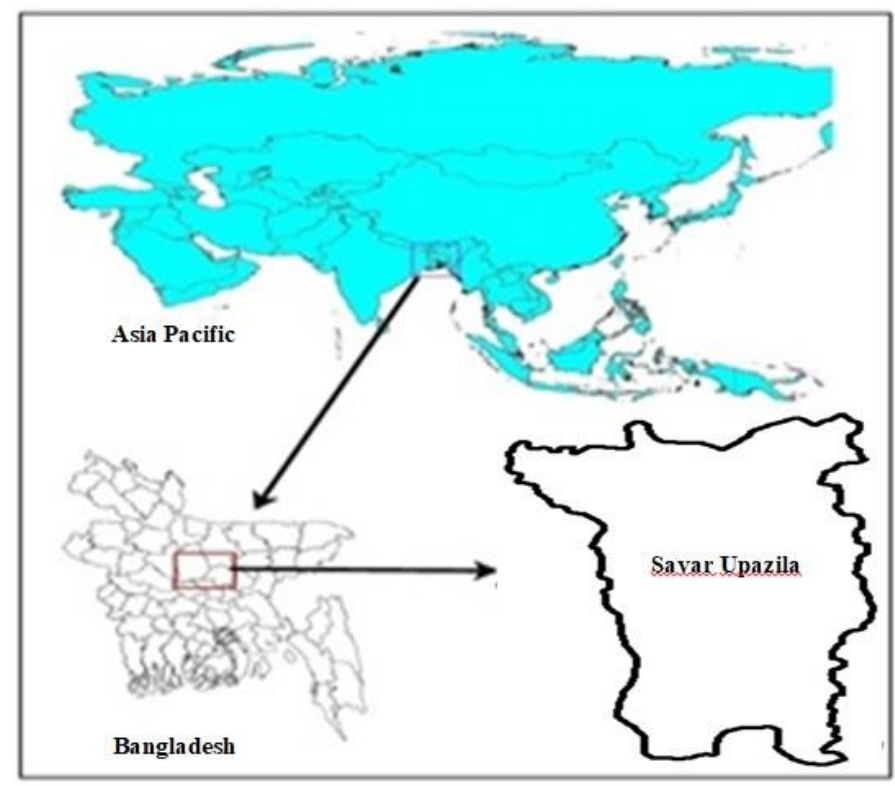

This publication is licensed under Creative Commons Attribution CC BY. 
Figure 1: Location map of the study area.

\section{Data and software used}

$\mathrm{V}$

arious types of data have been used for the present study. Table 1 provides a list of the satellite data and ancillary data that have been used for the present study.

Table 1: List of remote sensing data and ancillary data used for the study

\begin{tabular}{|l|l|l|}
\hline \multicolumn{1}{|c|}{ Satellite/Sensor } & \multicolumn{1}{|c|}{ Acquisition Dates } & \multicolumn{1}{c|}{ Ancillary data } \\
\hline Aerial Photo & November 1983 & $\begin{array}{l}\text { As ancillary data, high resolution data from Google Earth and } \\
\text { SPARRSO archive, administrative boundary from Survey of } \\
\text { Bangladesh were used. }\end{array}$ \\
\hline Sentinel 2 & November 2020 & \\
\hline
\end{tabular}

Besides these, historical maps and insitu data of this area have also been used. Field photographs acquired by digital camera have also been used. ERDAS IMAGINE and Arc/Info software has been used for data generation and vector layer analysis and management.

\section{Methodology}

Cloud-free Sentinel 2 data on November 2020 has been downloaded from Sentinel Hub (https://scihub.copernicus.eu/dhus/\#/home

) website. Extraction of different bands data has been done and then layer stacking of has been conducted for making the multi bands images. Band 2 (Blue), Band 3 (Green), Band 4 (Red) and Band 8 (Near Infra Red) were considered for layer stacking. Sentinel 2 observation of the study area and surrounding displaying Band 8, Band 4 and Band 3 (in RGB channels) on November 2020 has been shown in figure 2 and figure 3 showed the study area musk Sentinel 2 image of 2020.

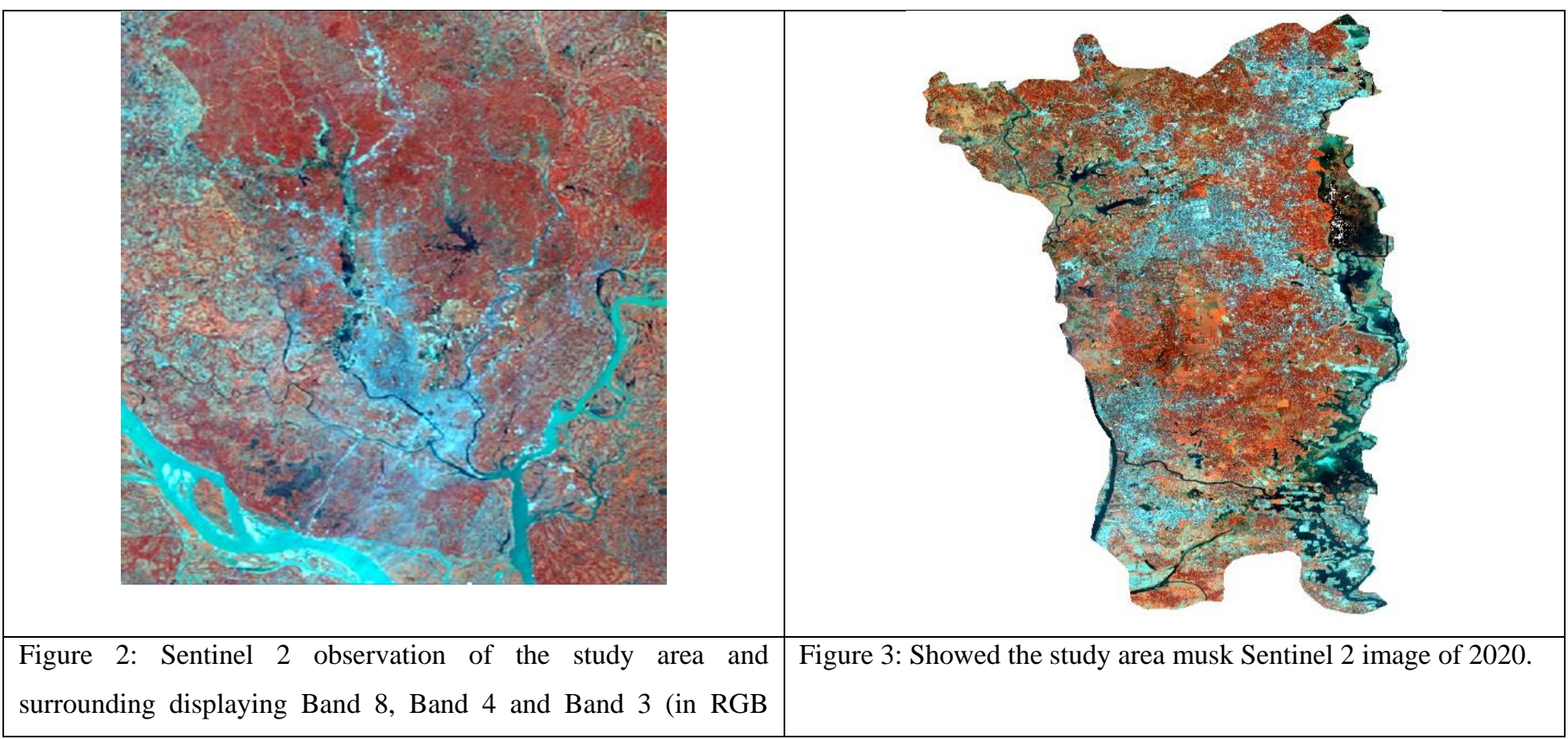


Aerial photographs of the study area were collected from Bangladesh Space Research and Remote Sensing Organization (SPARRSO) archive under closed supervision. The main target of this study was to delineate the different land use land cover classes. On screen digitization has been performed to delineate the different land use land cover classes. Global Positioning System (GPS) based ground verification has also been conducted in different land cover classes to delineate accurately the land cover classes in the study area. Ground photographs have also been taken during ground truthing. The whole methodology of the study has been shown in figure 4 .

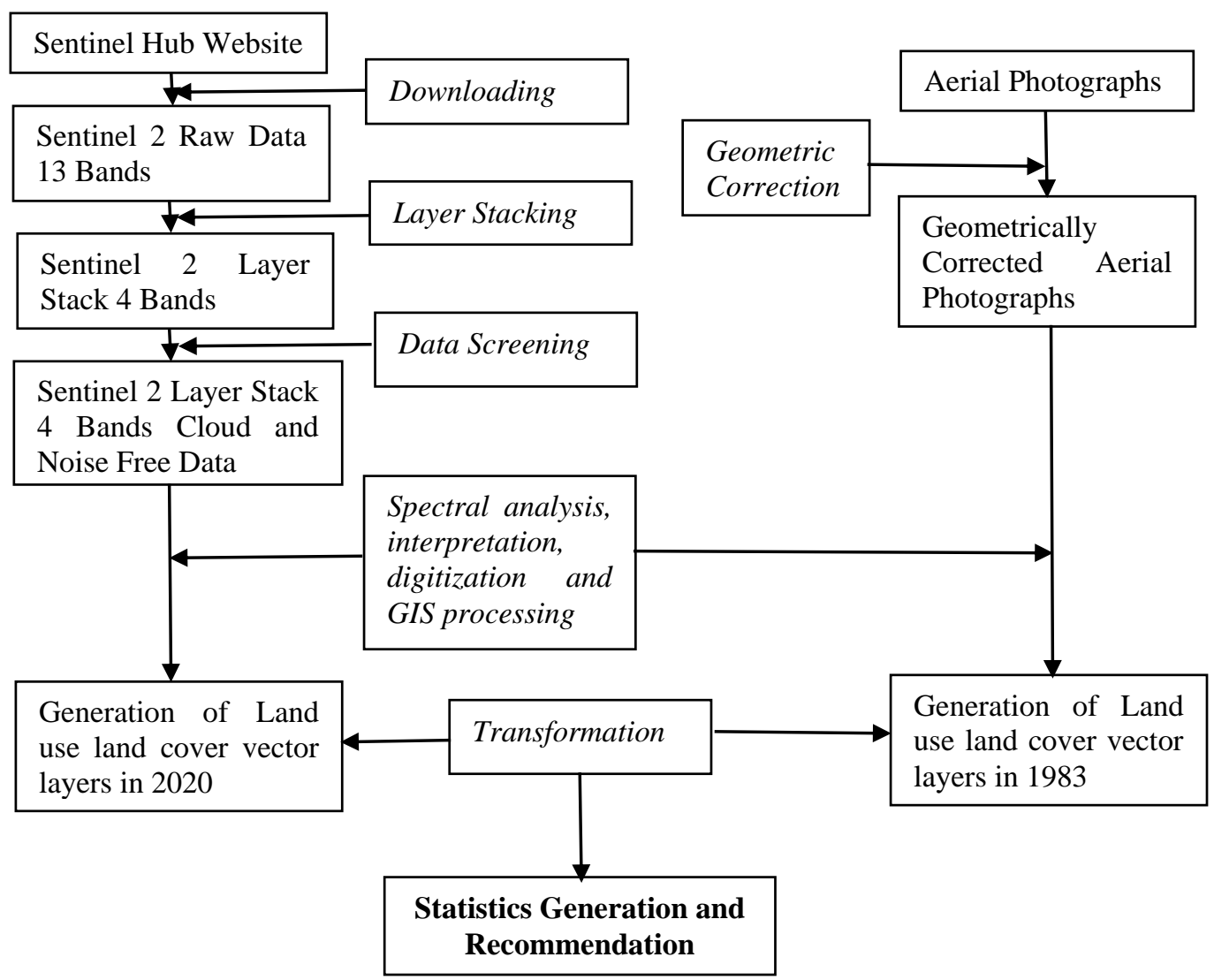

Figure 4: Shows the whole methodology of the research.

\section{RESEARCH FINDINGS AND DISCUSSIONS}

\section{Mapping land use and land cover in study area}

The map of land use and land cover of the study area has been shown in figure 4 and 5 respectively for the year 1983 and 2000.

There are 6 (six) identified classes of land use and land cover. Individual land use and land cover area has been shown in Table 2.

The total area of land use and land cover classes is 34995.9 ha. 
The map of land use and land cover of the study area has been mapped for the year 1983 and 2020 . Then the comparison has been made between the year 1983 and 2000 (Figure 5 \& 6). 'Agriculture' and 'Bare land and Others', these two land use and land cover classes area has been decreased in 2000 compare to 1983. The decrease of 'Agriculture' and 'Bare land and Others' by area is 1347.69 ha and 12862.86 respectively. These two classes area were decreased $21.79 \%$ and $59.69 \%$ respectively. The other four land use and land cover classes area has been increased in 2020 compare to 1983. The increase of 'Forestry', 'Industry', 'Settlement' and 'Waterbodies' by area is 866.64 ha, 749.47 ha, 9571.63 ha and 3022.81 ha respectively. These four classes area were increased 26.27 $\%, 859.68 \%, 350.33 \%$ and $264.46 \%$ respectively. In 1983 'Bare land and Others' was in first position by percentage of total area $(61.58 \%)$ and 'Agriculture' was in the second position by percentage of total area (17.67\%). Whereas in 2020 'Settlement' raised to first position by percentage of total area $(35.16 \%)$, 'Bare land and Others' dropped to second position by percentage of total area $(24.83 \%)$ and 'Agriculture' dropped to third position by percentage of total area (13.82\%).



Figure 5: Landuse Map of the study area for the year 1983.

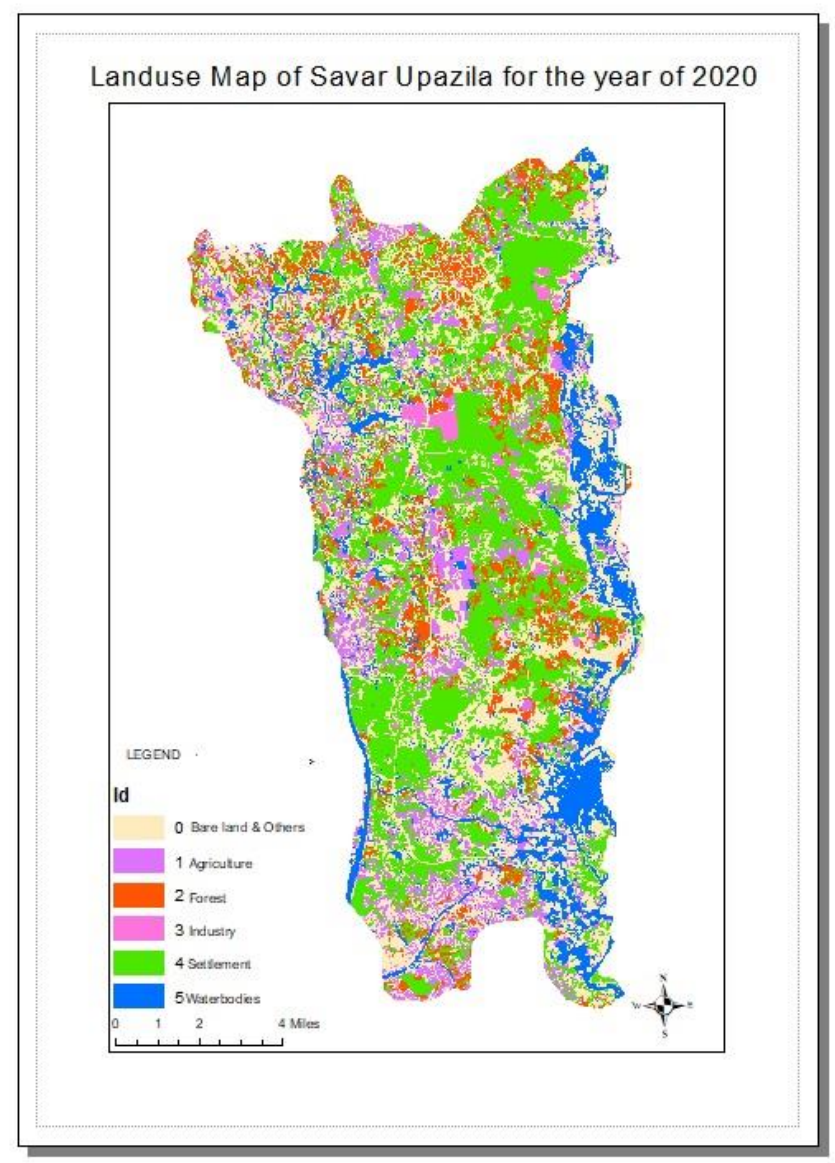

Figure 6: Landuse Map of the study area for the year 2020

Table 2: Shows the changes land use and land cover of the study area between $1983 \& 2020$.

\begin{tabular}{|c|c|c|c|c|c|c|c|}
\hline \multirow[t]{2}{*}{ Sl. } & \multirow[t]{2}{*}{$\begin{array}{l}\text { Name of } \\
\text { Class }\end{array}$} & \multicolumn{2}{|c|}{$\begin{array}{l}\text { Land use and land } \\
\text { cover in } 1983\end{array}$} & \multicolumn{2}{|c|}{$\begin{array}{l}\text { Land use and land cover in } \\
\qquad 2020\end{array}$} & \multicolumn{2}{|c|}{ Land use and land cover Changed from 1983 to 2020} \\
\hline & & Area (ha) & $\begin{array}{c}\text { Area } \\
(\%)\end{array}$ & Area (ha) & Area (\%) & Area (ha) & Area $(\%)$ \\
\hline
\end{tabular}

This publication is licensed under Creative Commons Attribution CC BY. http://dx.doi.org/10.29322/IJSRP.11.12.2021.p12057 


\begin{tabular}{|l|l|c|c|c|c|c|c|}
\hline 1 & Agriculture & 6184.08 & 17.67 & 4836.39 & 13.82 & 1347.69 (Decrease) & 21.79 \\
\hline 2 & Forestry & 3298.68 & 9.43 & 4165.32 & 11.90 & 866.64 (Increase) & 26.27 \\
\hline 3 & Industry & 87.18 & 0.25 & 836.65 & 2.39 & 749.47 (Increase) & 859.68 \\
\hline 4 & Settlement & 2732.16 & 7.81 & 12303.79 & 35.16 & 9571.63 (Increase) & 350.33 \\
\hline 5 & Waterbodies & 1143.02 & 3.27 & 4165.83 & 11.90 & 3022.81 (Increase) & 264.46 \\
\hline 6 & $\begin{array}{l}\text { Bare land } \\
\text { and Others }\end{array}$ & 21550.78 & 61.58 & 8687.92 & 24.83 & 12862.86 (Decrease) & 59.69 \\
\hline \multicolumn{2}{l}{ Total } & 34995.9 & 100.00 & 34995.9 & 100.00 & - & - \\
\hline
\end{tabular}

\section{Driving forces for changes of land use and land cover in study area between $1983 \& 2020$}

$\mathrm{A}_{\mathrm{n}}$ attempt has been made to identify the driving forces behind the changes of land use and land cover classes in the study area. Individual survey and focused group discussion had been conducted during ground truthing. People from different profession, age, sex, literacy, habitat (urban, sub-urban) etc. were considered for addressing the representative sampling. A large volume of 'Settlement' area has been increased between the years 1983 to 2020. 'Settlement' increased as normal growth of population increased and migrant workers for industries from different parts of the country came to the study area and settled down seeing the better scope of job opportunities. It has also been found that a large volume of 'Bare land and Others' was there in the year 1983 but in 2020 and some of those lands has been converted to 'Settlement' areas and some of those lands has also been converted into homestead forests. It has been found in the year 1983 there was very few industries in the study area but in the year 2020 many industries boomed up. Considering the cropping season aerial photograph of 1983 has been analyzed it has been found that lots of crop has been cultivated in the low land of Turag river and its surrounding low land areas. But in the same season of the year in 2020 image analyzed results revealed that some of those areas were under waterlogged condition. During ground truthing field data collection personal interview of the local people indicated that industrial waste water are causing waterlogged areas during the dry season of the year. Industrial waste water cannot flow off because the riverbed has become higher than previous time due to the deposition of waste materials of brickfields and others development activities. Surprisingly local people are happy because they are getting more return as rent from those water logged area compare to crop cultivation. The concepts of sustainable land use are ignored here only to looking at the present return from the lands.

The following driving forces may be identified:

- The major drivers of these changes were population growth and household and industry expansion,

- Higher financial returns from agricultural land for non-agricultural uses,

- Very close-proximity to the capital city center and

- $\quad$ Lack of awareness to the environmental issues.

\section{CONCLUSION}

The present study revealed that the remote sensing and GIS are useful technique and tool identification and assessment of land use and land cover changes analysis in the study area. Land use and land cover changes have been occurred significantly in the study area during 1983 to 2020. Cropping land is under tremendous pressure through building the new housing projects for settlements, construction of industrial structures, urban transportation facilities and communication systems. People in the study area are losing their cultivated land for irresponsible disposal of industrial waste water. Industrial waste water is very much harmful for ecology and 
environment of the region. So responsible authority should regulate and force the owner of the industries to clean up their waste water and dispose it to proper sewerage system. Assessment of Land use and Land Cover Changes of Savar Upazila might be helpful to make proper plan for development activities in the area.

\section{ACKNOLEDGEMENT}

The research team is grateful to Chairman SPARRSO as the funding required for the research has been allotted from the annual research budget of SPARRSO.

\section{REFERENCES}

1. Gain, P. 1998. Forests. In Gain, P. (2 $2^{\text {nd }}$ ed:), "Bangladesh Environment: facing the 21st century, SEHD. Dhaka. Bangladesh.” 6993.

2. M. F. Haque, M. S. Ali, M. A. Haq and M. M. R. Akhand, 2012. "Land Classification for Optimal Use of Land by Remote Sensing and GIS Technology”. J. Environ. Sci. \& Natural Resources, 5(1): 229-237.

3. Md. Shahjahan Ali, S.M. Mizanur Rahman, Abu Mohammad, Shyamal Baran Saha S.A.M. Arif-Ul-Haque, Ms. Nazma, and Ashfaque Ahmed. 2018. "Land use And Landcover Changes and Their Geo-Environmental Impacts in Nachole Upazila Under Chapai-Nawabgange District of Bangladesh: A RS and GIS Approach.” International Journal of Research- Granthaalayah, 6(9), pp.351-355.

4. Md. Shahjahan Ali, Sukumar Dutta, Abu Taleb Pramanik, S.A.M. Arif-ul_Haque, Md. S. M. Mizanur Rahman, Ms Nazma and Ashfaque Ahmed, 2017. “Assessment of Land use and Land Cover Changes in St. Martin's Island, Cox's Bazar, Bangladesh using RS and GIS Technology.” Peer Reviewed International Journal, IJSD, Ranchi, India, Vol. 5(4), pp. 226-233.

5. Riches, C. R. 2008. The High Barind Tract: a challenging Drought- prone agricultural environment. In: Riches, C.R., Harris, D., Johnson, D.E. and Hardy, B., (Eds.) Improving agricultural productivity in rice-based systems of the High Barind Tract of Bangladesh. International Rice Research Institute, Los Banos (Philippines), pp.3-6

6. S. Rahman, H. Rahman \& M. Keramat, 2007. Study on the seasonal changes of land cover and their impact on surface albedo in the northwestern part of Bangladesh using remote sensing, International Journal of Remote Sensing, 28:5, 1001-1022

7. Solanke, P, R. Srivastava, J. Prasad, M, Nagaraju, R. Saxena \&A. Barthwal, 2005. "Application of remote sensing and GIS in watershed characterization and management, Journal of the Indian Society of Remote Sensing 33(2):239-244.

\section{AUTHORS}

First Author - Md. Shahjahan Ali, Principal Scientific Officer, Bangladesh Space Research and Remote Sensing Organization (SPARRSO), Agargaon, Sher-e-Bangla Nagar, Dhaka-1207, Bangladesh Email: shopanali65@yahoo.com

Second Author - Md. Abdus Salam Ph.D, Chief Scientific Officer, Bangladesh Space Research and Remote Sensing Organization (SPARRSO), Agargaon, Sher-e-Bangla Nagar, Dhaka-1207, Bangladesh Email: salam2bd@gmail.com 
International Journal of Scientific and Research Publications, Volume 11, Issue 12, December 2021

Correspondence Author - Md. Abdus Salam Ph.D, Chief Scientific Officer, Bangladesh Space Research and Remote Sensing Organization (SPARRSO), Agargaon, Sher-e-Bangla Nagar, Dhaka-1207, Bangladesh Email: salam2bd@gmail.com 